\title{
Penerapan Metode Simpleks Untuk Meningkatkan Keuntungan Produksi
}

\author{
Tirsa Ninia Lina ${ }^{1}$, Belinda Sicilia Marlissa ${ }^{1}$, Matheus Supriyanto Rumetna ${ }^{1, *}$, Joseph Eliza Lopulalan² \\ ${ }^{1}$ Fakultas Ilmu Komputer, Program Studi Sistem Informasi, Universitas Victory Sorong, Sorong, Indonesia \\ ${ }^{2}$ Fakultas Ilmu Sosial, Program Studi Administrasi Publik, Universitas Victory Sorong, Sorong, Indonesia \\ Email: ${ }^{1}$ tirsawp@gmail.com, ${ }^{1}$ siciliabelinda17@gmail.com, ${ }^{1,}{ }^{*}$ matheus.rumetna@gmail.com, ${ }^{2}$ josephlopulalan@gmail.com \\ Email Penulis Korespondensi: matheus.rumetna@gmail.com \\ Submitted 15-05-2020; Accepted 08-06-2020; Published 14-06-2020
}

\begin{abstract}
Abstrak
Usaha Oma Corry adalah usaha roti berskala kecil di Kota Sorong, Provinsi Papua Barat. Salah satu masalah yang dihadapi oleh Usaha Oma Corry yaitu masalah menghitung atau menentukan keuntungan maksimum yang diperoleh setiap hari dari kegiatan produksi. Untuk menghitung keuntungan Roti Ampas Terigu dan Babengka masih menggunakan kalkulator dan menulis di buku sehingga kurang efisien. Sedangkan sekarang perhitungan keuntungan maksimum harus diselesaikan dengan cepat dan tepat, sehingga perlu sebuah sistem yang dapat memberikan kenyamanan dalam menghitung keuntungan. Untuk mencapai tujuan ini, maka metode simpleks dipilih untuk proses perhitungan secara manual dan tools POM-QM for Windows digunakan untuk mempercepat proses perhitungan. Hasilnya adalah keuntungan maksimum yang didapatkan adalah Rp 494,000 setiap harinya dan proses perhitungan menjadi lebih efisien.
\end{abstract}

Kata Kunci: Operational Research, Linear Programming, Simplex Methods, Maximizing Profits, POM-QM for windows

Abstract

Oma Corry's business is a small-scale bread business in Sorong City, West Papua Province. One of the problems faced by Oma Corry Enterprises is the problem of calculating or determining the maximum profit gained every day from production activities. To calculate the benefits of Bread and Flour Bread and Babengka still use a calculator and write in books so it is less efficient. Whereas now the calculation of maximum profits must be completed quickly and precisely, so we need a system that can provide convenience in calculating profits. To achieve this goal, the simplex method is chosen for the manual calculation process and the POM-QM for Windows tool is used to speed up the calculation process. The result is a maximum profit of IDR 494,000 per day and a more efficient calculation process.

Keywords: Operational Research, Linear Programming, Simplex Methods, Maximizing Profits, POM-QM for windows

\section{PENDAHULUAN}

Usaha Oma Corry adalah usaha roti berskala kecil di Kota Sorong, Provinsi Papua Barat. Oma Corry sudah berjualan kurang lebih 10 bulan, usaha roti ini dibangun untuk memenuhi kebutuhan hidup sehari-hari. Oma Corry memproduksi 2 jenis roti yaitu Ampas Terigu dan Babengka yang adalah makanan khas Kota Ambon, Provinsi Maluku. Kegiatan produksi yang dilakukan Oma Corry saat ini belum diketahui apakah sumber daya yang tersedia digunakan secara optimal atau belum, sehingga keuntungan yang diperoleh belum tentu maksimal. Perencanaan produksi yang optimal dengan mempertimbangkan faktor-faktor produksi belum dilakukan oleh Oma Corry.

Agar terjaga kelangsungan dan berkembangnya usaha produksi roti ini, komponen atau variabel pendukung produksi tidak mungkin hanya terbatas dua variabel saja. Untuk itulah dibutuhkan sebuah metode yang dapat menangani permasalahan produksi yang lebih komplek [1],[2],[3],[4]. Metode Simpleks adalah bagian dari Program Linier (PL) dan dapat digunakan karena metode ini dapat mengkombinasikan antara bahan baku serta keuntungan yang diperoleh [5],[6],[7].

PL merupakan salah satu alat analisis yang banyak digunakan oleh perusahaan dalam perencanaan agregat untuk menemukan kombinasi optimal dari keterbatasan sumber daya yang dimiliki [8],[9]. Persoalan PL menggunakan metode simpleks sangat membantu karena mempermudah dalam pengambilan keputusan dan memberikan solusi yang paling baik untuk pemecahan masalah. Metode ini dapat digunakan untuk masalah optimasi dalam industri, produksi campuran, penjadwalan, masalah transportasi, logistik, dll.

Metode ini memiliki tiga hal penting [10],[11], yaitu:

1) Variabel keputusan (decision variables): $\mathrm{x} 1, \mathrm{x} 2, \ldots, \mathrm{xn}$ merupakan variabel yang dipilih menjadi keputusan berdasarkan nilainya.

2) Fungsi tujuan (objective function): $Z=f(x 1, x 2, \ldots, x n)$ merupakan fungsi yang akan dioptimasi (dimaksimumkan atau diminimumkan).

3) Pembatasan (constraints): gi $(x 1, x 2, \ldots, x n) \leq b i$ adalah pembatasan-pembatasan yang harus dipenuhi.

Penelitian ini dilakukan dengan memanfaatkan teknologi informasi yaitu penggunaan tools POM-QM for windows untuk mempermudah menentukan dan menghitung keuntungan maksimum yang diperoleh dari setiap produksi yang dilakukan oleh Oma Corry dalam jangka waktu satu hari dengan tepat, sehingga memiliki perhitungan yang akurat dan diharapkan dapat mempermudah dan mempercepat proses perhitungan.

\section{METODE PENELITIAN}

Adapun metode atau langkah-langkah dalam melakukan penelitian ini yaitu [7],[10],[12],[13]:

1) Identifikasi Masalah,

Oma Corry ingin memanfaatkan keterbatasan bahan baku tepung terigu, gula putih, gula merah, telur, dan kelapa untuk medapatkan keuntungan yang maksimal. 
2) Pemilihan Model Pemecahan Masalah

PL menggunakan Metode Simpleks digunakan untuk pemecahan masalah.

3) Pengumpulan Data

Observasi dan wawancara dengan Oma Corry digunakan untuk pengumpulan data. Data yang digunakan adalah data bahan baku produksi, produksi yang dihasilkan, jumlah produksi, dan keuntungan produk perhari.

4) Pengolahan Data dan Analisis

Pengolahan data dan analisis mengunakan Metode Simpleks pada PL dengan aplikasi POM-QM for windows.

5) Implementasi Model

Pemodelan PL dilakukan dengan menggunakan Metode Simpleks. Berikut langkah-langkahnya [8, 9]:

a. Mengubah fungsi tujuan dengan batasan, yaitu $C j X i j$ digeser ke kiri.

Contoh: $\mathrm{Z}=40 \mathrm{X} 1+35 \mathrm{X} 2$ menjadi $\mathrm{Z}-40 \mathrm{X} 1$ - 35X2. Kemudian hasilnya dimasukkan ke dalam tabel Simpleks.

b. Memilih kolom kunci, yaitu memilih kolom yang fungsi tujuannya memiliki nilai negatif yang terbesar.

c. Memilih baris kunci. Pilih baris yang mempunyai limit rasio dengan angka terkecil.

Limit rasio = nilai kanan / nilai kolom kunci.

d. Mengubah nilai baris kunci. Yaitu membagi nilai baris kunci dengan angka kunci, ganti variabel dasar pada baris kunci dengan variabel yang terdapat dibagian atas kolom kunci.

e. Mengubah nilai-nilai selain pada baris kunci. Caranya:

Baris baru = baris lama - (koefisien per kolom kunci $*$ nilai baris kunci).

f. Lanjutkan perbaikan dengan cara ulangi langkah $\mathrm{c}-\mathrm{f}$, sampai semua nilai pada fungsi tujuan bernilai positif.

6) Evaluasi Hasil

Evaluasi hasil dilakukan dengan membandingkan antara hasil penelitian dengan kondisi aktual yang dialami oleh Oma Corry [10].

7) Melaksanakan Solusi Terpilih

Hal ini adalah wewenang dari pihak Oma Corry dengan mempertimbangkan hasil dari penerapan metode Simpleks. Hal ini juga dijadikan sebagai bahan pertimbangan dalam pengambilan keputusan.(Ukm et al., 2019)

Langkah-langkah penelitian di atas dapat di lihat dengan jelas pada Gambar 1.

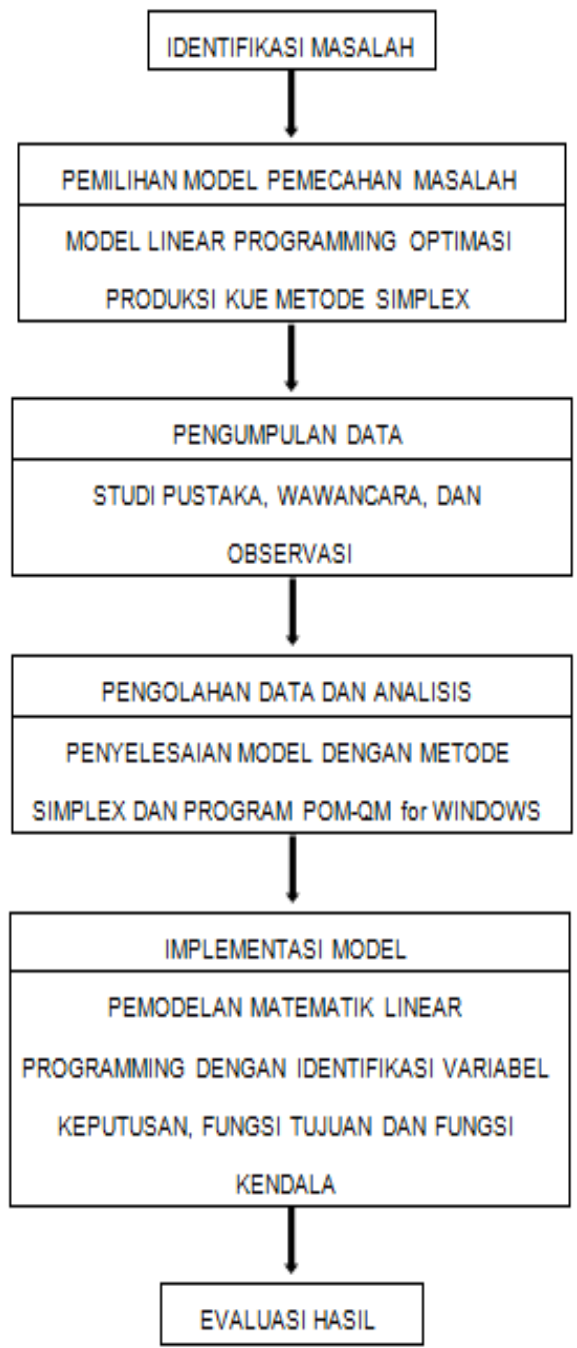

Gambar 1. Diagram Alur Penelitian 


\section{HASIL DAN PEMBAHASAN}

Berdasarkan hasil wawancara dengan Oma Corry didapatkan variabel keputusan sebagai berikut:

1) Roti Ampas Terigu memerlukan:
a. Tepung Terigu $5 \mathrm{Kg}$
b. Gula Putih $2.5 \mathrm{Kg}$
c. Telur 5 butir

2) Kue Babengka memerlukan:
a. Tepung Terigu $5 \mathrm{Kg}$
b. Gula Merah $2.5 \mathrm{Kg}$
c. Kelapa 5 buah

Bahan baku ini diperlukan untuk pembuatan roti sesuai dengan jumlah produksi dan diasumsikan sesuai juga dengan permintaan konsumen. Sehingga memperoleh keuntungan sebesar:

1) Roti Ampas Terigu Rp. 271.000,-

2) Kue Gula Merah Rp. 115.500,-

Sedangkan bahan baku yang tersedia yaitu:

1) Tepung Terigu $20 \mathrm{~kg}$

2) Gula Putih $4 \mathrm{~kg}$

3) Telur 7 butir

4) Gula Merah $3 \mathrm{~kg}$

5) Kelapa 5 buah

Untuk menentukan formulasi di atas, digunakan simbol X1, X2, dan Z dimana:

$\mathrm{X} 1=$ jumlah bahan baku roti ampas terigu dalam satu hari

$\mathrm{X} 2=$ jumlah bahan baku babengka dalam satu hari

$\mathrm{Zmax}=$ jumlah keuntungan roti ampas terigu dan babengka

Tujuan Oma Corry adalah dengan keterbatasan sumber saya yang ada dapat dimanfaatkan untuk memperoleh keuntungan yang maksimal. sehingga formulasinya adalah:

Memaksimumkan $\mathrm{Z}=271.000 \mathrm{X} 1+115.500 \mathrm{X} 2$

Berikut formulasi batasan-batasan yang dibuat sesuai dengan keterbatasan sumber daya (dapat juga dilihat pada Tabel 1):

1) Tepung terigu yang digunakan adalah $5 \mathrm{~kg}$ untuk roti ampas terigu (X1) dan $5 \mathrm{~kg}$ untuk babengka (X2) kapasitas yang tersedia adalah $20 \mathrm{~kg}$

2) Gula Putih yang digunakan $2.5 \mathrm{~kg}$ (X1) kapassitas yang tersedia $4 \mathrm{~kg}$

3) Gula merah yang digunakan $2.5 \mathrm{~kg}(\mathrm{X} 2)$ kapasitas yang tersedia $3 \mathrm{~kg}$

4) Telur yang digunakan 5 butir (X1) kapasitas yang tersedia 7 butir

5) Kelapa yang digunakan 5 buah (X2) kapasitas yang tersedia 5 buah

Tabel 1. Jenis produksi, kapasitas dan keuntungan

\begin{tabular}{cccc}
\hline Bahan Baku & \multicolumn{2}{c}{ Jenis Produk } & Kapasitas \\
\cline { 2 - 3 } & Ampas Terigu & Babengka & (Satuan) \\
\hline Tepung terigu & $5 \mathrm{Kg}$ & $5 \mathrm{Kg}$ & $20 \mathrm{Kg}$ \\
Gula pasir & $2.5 \mathrm{Kg}$ & - & $4 \mathrm{Kg}$ \\
Gula merah & - & $2.5 \mathrm{Kg}$ & $3 \mathrm{Kg}$ \\
Telur & 5 butir & - & 7 butir \\
Kelapa & - & 5 buah & 5 buah \\
\hline Keuntungan & Rp. 271.000,- & Rp.115.00,- \\
\hline
\end{tabular}

Langkah-langkah penyelesaian PL dari Tabel 1 adalah sebagi berikut:

1) $5 \times 1+5 \times 2 \leq 20$

$5 \mathrm{X} 1+5 \mathrm{X} 2=20$

2) $2.5 \times 1 \leq 4$

$2.5 \times 1=4$

3) $2.5 \times 2 \leq 3$

$2.5 \times 2=3$

4) $5 \times 1 \leq 7$

$5 \times 1=7$

5) $5 \times 2 \leq 5$

$5 \times 2=5$

Fungsi tujuan diubah menjadi:

$\mathrm{Z}-271.000 \mathrm{X} 1-115.5000 \mathrm{X} 2=0$ 
Fungsi batasan diubah dengan memberikan variable slack menjadi:

1) $5 \mathrm{X} 1+5 \mathrm{X} 2 \leq 20$ diubah menjadi $5 \mathrm{X} 1+5 \mathrm{X} 2+\mathrm{S} 1=20$

2) $2.5 \times 1 \leq 4$ diubah menjadi $2.5 \times 1 \quad+\mathrm{S} 2=4$

3) $2.5 \times 2 \leq 3$ diubah menjadi $2.5 \times 2+\mathrm{S} 3=3$

4) $5 \times 1 \leq 7$ diubah menjadi $5 \times 1 \quad+\mathrm{S} 4=7$

5) $5 \times 2 \quad \leq 5$ diubah menjadi $5 \times 2 \quad+\mathrm{S} 5=5$

Tabel 2):

Persamaan-persamaan di atas dimasukan ke dalam tabel Simplex untuk mengetahui formulasi dari permasalahan (lihat

Tabel 2. Formulasi

\begin{tabular}{lccccccccc}
\hline Var & Z & X1 & X2 & S1 & S2 & S3 & S4 & S5 & NK \\
\hline Z & 1 & -271000 & -115500 & 0 & 0 & 0 & 0 & 0 & 0 \\
S1 & 0 & 5 & 5 & 1 & 0 & 0 & 0 & 0 & 20 \\
S2 & 0 & 2.5 & 0 & 0 & 1 & 0 & 0 & 0 & 4 \\
S3 & 0 & 0 & 2.5 & 0 & 0 & 1 & 0 & 0 & 3 \\
S4 & 0 & 5 & 0 & 0 & 0 & 0 & 1 & 0 & 7 \\
S5 & 0 & 0 & 5 & 0 & 0 & 0 & 0 & 1 & 5 \\
\hline
\end{tabular}

6) Memilih kolom kunci (lihat Tabel 3)

Tabel 3. Kolom kunci

\begin{tabular}{lccccccccc}
\hline Var & $\mathrm{Z}$ & $\mathrm{X} 1$ & $\mathrm{X} 2$ & $\mathrm{~S} 1$ & $\mathrm{~S} 2$ & $\mathrm{~S} 3$ & $\mathrm{~S} 4$ & $\mathrm{~S} 5$ & $\mathrm{NK}$ \\
\hline $\mathrm{Z}$ & 1 & -271000 & -115500 & 0 & 0 & 0 & 0 & 0 & 0 \\
S1 & 0 & 5 & 5 & 1 & 0 & 0 & 0 & 0 & 20 \\
S2 & 0 & 2.5 & 0 & 0 & 1 & 0 & 0 & 0 & 4 \\
S3 & 0 & 0 & 2.5 & 0 & 0 & 1 & 0 & 0 & 3 \\
S4 & 0 & 5 & 0 & 0 & 0 & 0 & 1 & 0 & 7 \\
S5 & 0 & 0 & 5 & 0 & 0 & 0 & 0 & 1 & 5 \\
\hline
\end{tabular}

Karena nilai X1 merupakan angka dengan nilai negatif paling besar yaitu -271000, maka kolom X1 merupakan kolom pivot dan X1 merupakan variabel masuk.

7) Memilih baris kunci (lihat Tabel 4)

Limit rasio = nilai kanan $(\mathrm{NK}) /$ nilai kolom kunci

Tabel 4. Baris kunci

\begin{tabular}{lcccccccccc}
\hline Var & $\mathrm{Z}$ & $\mathrm{X} 1$ & $\mathrm{X} 2$ & $\mathrm{~S} 1$ & $\mathrm{~S} 2$ & $\mathrm{~S} 3$ & $\mathrm{~S} 4$ & $\mathrm{~S} 5$ & $\mathrm{NK}$ & Inde \\
\hline $\mathrm{Z}$ & 1 & -271000 & -115500 & 0 & 0 & 0 & 0 & 0 & 0 & 0 \\
S1 & 0 & 5 & 5 & 1 & 0 & 0 & 0 & 0 & 20 & 4 \\
S2 & 0 & 2.5 & 0 & 0 & 1 & 0 & 0 & 0 & 4 & 1.6 \\
S3 & 0 & 0 & 2.5 & 0 & 0 & 1 & 0 & 0 & 3 & $\sim$ \\
S4 & 0 & 5 & 0 & 0 & 0 & 0 & 1 & 0 & 7 & 1.4 \\
S5 & 0 & 0 & 5 & 0 & 0 & 0 & 0 & 1 & 5 & $\sim$ \\
\hline
\end{tabular}

$\mathrm{X} 1$ = Kolom Kunci

S4 = Baris Kunci

8) Mengubah nilai pada bari kunci

Nilai pertama adalah nilai baris pivot baru yaitu X1, semua nilai pada baris S4 dibagi dengan 5 (elemen pivot) Keterangan:

a. Nilai baris kunci / angka kunci

b. Nilai kunci yaitu nilai pada baris S4 klom baris kunci. Angka kunci yaitu variabel keluar / elemen pivot (5)

Nilai baris kunci diubah dengan cara dibagi dengan angka kunci, yaitu:
a) $5 / 5=1$
e) $1 / 5=0,2$
b) $0 / 5=0$
f) $0 / 5=0$
c) $0 / 5=0$
g) $7 / 5=1,4 \quad 0 / 5=0$

Iterasi 1, hasil pembagian dimasukkan pada baris baru yaitu X1 dimana baris S4 diubah menjadi baris S4 (lihat Tabel 5).

Tabel 5. Perubahan baris kunci

\begin{tabular}{cccccccccc}
\hline Var & $\mathrm{Z}$ & $\mathrm{X} 1$ & $\mathrm{X} 2$ & $\mathrm{~S} 1$ & $\mathrm{~S} 2$ & $\mathrm{~S} 3$ & $\mathrm{~S} 4$ & $\mathrm{~S} 5$ & $\mathrm{NK}$ \\
\hline $\mathrm{Z}$ & 1 & -271000 & -115500 & 0 & 0 & 0 & 0 & 0 & 0
\end{tabular}




\begin{tabular}{cccccccccc} 
S1 & 0 & 5 & 5 & 1 & 0 & 0 & 0 & 0 & 20 \\
S2 & 0 & 2,5 & 0 & 0 & 1 & 0 & 0 & 0 & 3 \\
S3 & 0 & 0 & 2,5 & 0 & 0 & 1 & 0 & 0 & 4 \\
S4 & 0 & 1 & 0 & 0 & 0 & 0 & 0,2 & 0 & 1,4 \\
S5 & 0 & 0 & 2.5 & 0 & 0 & 0 & 0 & 1 & 0 \\
\hline
\end{tabular}

9) Mengubah nilai-nilai selain baris kunci. Keterangan:

a. Baris lama = baris Z, baris S1, S2, S3, S4 dan S5

b. Koefisien perkolom kunci yaitu $-271.000,5,2,5,0$ dan 0

c. Nilai baris kunci $=$ nilai pada baris kunci baru (S4)

\begin{tabular}{ccccccccc}
\multicolumn{2}{l}{ Baris Z } \\
\hline $\mathrm{Z}$ & -271.000 & -115.500 & 0 & 0 & 0 & 0 & 0 & 0 \\
$\mathrm{~S} 4$ & 1 & 0 & 0 & 0 & 0 & 0,2 & 0 & 1,4 \\
\hline
\end{tabular}

Hasil bari baru adalah:
a. $\quad-271.000-(-271.000-1)=0$
b. $-115.500-(-271.000-0)=-115.500$
c. $0-(-271.000-0)=0$
d. $0-(-271.000-0)=0$
e. $0-(-271.000-0)=0$
f. $\quad 0-(-271.000-0,2)=54.200$
g. $\quad 0-(-271.000-0)=0$
h. $\quad 0-(-271.000-1,4)=379.400$

Maka hasil yang didapat dari perhitungan Baris $\mathrm{Z}$ adalah 0, -115.500, 0, 0, 0, 54.200, 0, 379.400

\begin{tabular}{ccccccccc}
\multicolumn{2}{l}{ Baris S1 } \\
\hline S1 & 5 & 5 & 1 & 0 & 0 & 0 & 0 & 20 \\
S4 & 1 & 0 & 0 & 0 & 0 & 0,2 & 0 & 1,4 \\
\hline
\end{tabular}

Hasil baris baru adalah:
a. $\quad 5-(5-1)=0$
b. $5-(5-0)=5$
c. $1-(5-0)=5$
d. $0-(5-0)=0$
e. $0-(5-0)=0$
f. $\quad 0-(5-0,2)=-0,2$
g. $0-(5-0)=0$
h. $20-(5-1,4)=13$

Maka hasil yang didapat dari perhitungan baris $\mathrm{S} 1$ adalah $0,5,5,0,0,-0,2,0,13$

\begin{tabular}{lcccccccc}
\multicolumn{2}{l}{ Baris S2 } \\
\hline S2 & 2,5 & 0 & 0 & 1 & 0 & 0 & 0 & 4 \\
S4 & 1 & 0 & 0 & 0 & 0 & 0,2 & 0 & 1,4 \\
\hline
\end{tabular}

Baris baru $=$ baris lama $-($ koefisien perkolom kunci $*$ nilai baris kunci $)$.
a. $\quad 2,5-(2,5-1)=0$
b. $0-(2,5-0)=0$
c. $0-(2,5-0)=0$
d. $1-(2,5-0)=1$
e. $0-(2,5-0)=0$
f. $\quad 0-(2,5-0,2)=-0,5$
g. $\quad 0-(2,5-0)=0$
h. $\quad 4-(2,5-1,4)=0,5$

Maka hasil yang didapat dari perhitungan S2 adalah 0, 0, 0, 1, 0, 0.5, 0 dan 0,5.

\begin{tabular}{ccccccccc}
\multicolumn{2}{l}{ Baris S3 } \\
\hline S3 & 0 & 2,5 & 0 & 0 & 1 & 0 & 0 & 3 \\
S4 & 1 & 0 & 0 & 0 & 0 & 0,2 & 0 & 1,4 \\
\hline
\end{tabular}


Baris baru $=$ baris lama - (koefisien perkolom kunci $*$ nilai baris kunci).
a. $\quad 0-(0-1)=0$
b. $2,5-(0-0)=2,5$
c. $0-(0-0)=0$
d. $0-(0-0)=0$
e. $1-(0-0)=1$
f. $\quad 0-(0-0,2)=0$
g. $\quad 0-(0-0)=0$
h. $3-(0-1,4)=3$

Maka hasil yang didapat dari perhitungan $\mathrm{S} 3$ adalah $0,2.5,0,0,1,0,0$ dan 3 .

\begin{tabular}{llllllllc}
\multicolumn{2}{l}{ Baris S5 } \\
\hline S5 & 0 & 5 & 0 & 0 & 0 & 0 & 1 & 5 \\
S4 & 1 & 0 & 0 & 0 & 0 & 0,2 & 0 & 1,4 \\
\hline
\end{tabular}

Baris baru $=$ baris lama - (koefisien perkolom kunci $*$ nilai baris kunci).
a. $0-(0-1)=0$
b. $5-(0-0)=5$
c. $0-(0-0)=0$
d. $0-(0-0)=0$
e. $0-(0-0)=0$
f. $\quad 0-(0-0,2)=0$
g. $\quad 1-(0-0)=1$
h. $5-(0-1,4)=5$

Maka hasil yang didapat dari perhitungan S5 adalah 0, 5, 0, 0, 0, 0, 1 dan 5 .

Masukkan nila-nilai baris baru ke dalam tabel (lihat Tabel 6).

Tabel 6. Perubahan nilai-nilai baris baru

\begin{tabular}{lccccccccc}
\hline Var & Z & X1 & X2 & S1 & S2 & S3 & S4 & S5 & NK \\
\hline Z & 1 & 0 & -115.500 & 0 & 0 & 0 & 54.200 & 0 & 379.400 \\
S1 & 0 & 0 & 5 & 5 & 0 & 0 & $-0,2$ & 0 & 13 \\
S2 & 0 & 0 & 0 & 0 & 1 & 0 & -0.5 & 0 & 0.5 \\
S3 & 0 & 0 & 2,5 & 0 & 0 & 1 & 0 & 0 & 3 \\
S4 & 0 & 1 & 0 & 0 & 0 & 0 & 0,2 & 0 & 1.4 \\
S5 & 0 & 0 & 5 & 0 & 0 & 0 & 0 & 1 & 5 \\
\hline
\end{tabular}

1) Iterasi 2, hasil pembagian dimasukkan pada baris baru yaitu $\mathrm{X} 2$ dimana baris $\mathrm{S} 5$ diubah menjadi baris $\mathrm{S} 5$ (lihat Tabel 7).

Tabel 7. Perubahan baris kunci

\begin{tabular}{lcccccccccc}
\hline Var & $\mathrm{Z}$ & $\mathrm{X} 1$ & $\mathrm{X} 2$ & $\mathrm{~S} 1$ & $\mathrm{~S} 2$ & $\mathrm{~S} 3$ & $\mathrm{~S} 4$ & $\mathrm{~S} 5$ & NK & Index \\
\hline Z & 1 & 0 & -115.500 & 0 & 0 & 0 & 54.200 & 0 & 379.400 & 0 \\
S1 & 0 & 0 & 5 & 5 & 0 & 0 & $-0,2$ & 0 & 13 & 2,6 \\
S2 & 0 & 0 & 0 & 0 & 1 & 0 & -0.5 & 0 & 0.5 & $\sim$ \\
S3 & 0 & 0 & 2,5 & 0 & 0 & 1 & 0 & 0 & 3 & 1,2 \\
S4 & 0 & 1 & 0 & 0 & 0 & 0 & 0,2 & 0 & 1,4 & $\sim$ \\
S5 & 0 & 0 & 1 & 0 & 0 & 0 & 0 & 0,2 & 1 & 1 \\
\hline
\end{tabular}

2) Mengubah nilai- nilai selain baris kunci. Keterangan :
a. $\quad$ Baris lama = baris Z, baris S1,S2,S3, dan S4
b. Koefisien perkolom kunci yaitu $-115.500,5,0,2.5$ dan 0 .
c. Nilai baris kunci $=$ nilai pada bais kunci baru (S5)

\begin{tabular}{lcccccccc}
\multicolumn{6}{l}{ Baris Z } \\
\hline Z & -115.500 & 0 & 0 & 0 & 54.200 & 0 & 379.400 & -115.500 \\
S5 & 1 & 0 & 0 & 0 & 0 & 0 & 0,2 & 1 \\
\hline
\end{tabular}

Hasil bari baru adalah:
a. $\quad-115.500-(-115.500-1)=0$
b. $0-(-115.500-0)=0$
c. $0-(-115.500-0)=0$
d. $\quad 0-(-115.500-0)=0$
e. $54.200-(-115.500-0)=54.200$ 
f. $\quad 0-(-115.500-0,2)=23.100$

g. $\quad 379.400-(-115.500-1)=494.900$

Maka hasil yang didapat dari perhitungan Baris Z adalah 0, 0, 0, 0, 54.200, 23.100, 494.900

\begin{tabular}{llllllccc}
\multicolumn{2}{l}{ Baris S1 } \\
\hline S1 & 5 & 5 & 0 & 0 & 0 & -0.2 & -1 & 13 \\
S5 & 1 & 0 & 0 & 0 & 0 & 0 & 0.2 & 1 \\
\hline
\end{tabular}

Hasil baris baru adalah:
a. $\quad 5-(5-1)=0$
b. $5-(5-0)=5$
c. $0-(5-0)=0$
d. $0-(5-0)=0$
e. $-0,2-(5-0)=-0,2$
f. $-1-(5-0,2)=-1$
g. $13-(5-1)=8$

Maka hasil yang didapat dari perhitungan baris S1 adalah $0,5,0,0,-0,2,1,8$

\begin{tabular}{lllllclll}
\multicolumn{2}{l}{ Baris S2 } \\
\hline S2 & 0 & 0 & 1 & 0 & $-0,5$ & 0 & 0,5 & 0 \\
S5 & 1 & 0 & 0 & 0 & 0 & 0 & 0.2 & 1 \\
\hline
\end{tabular}

Baris baru $=$ baris lama - (koefisien perkolom kunci $*$ nilai baris kunci).
a. $\quad 0-(0-1)=0$
b. $0-(0-0)=0$
c. $1-(0-0)=1$
d. $0-(0-0)=0$
e. $-0,5-(0-0)=-0,5$
f. $\quad 0-(0-0,2)=0$
g. $\quad 0,5-(0-1)=0,5$

Maka hasil yang didapat dari perhitungan S2 adalah 0, 0, 1, 0, -0.5, 0 dan 0,5.

\begin{tabular}{lcccccccc}
\multicolumn{2}{l}{ Baris S3 } \\
\hline S3 & 2,5 & 0 & 0 & 1 & 0 & 0 & 3 & 2,5 \\
S5 & 1 & 0 & 0 & 0 & 0 & 0 & 0.2 & 1 \\
\hline
\end{tabular}

Baris baru $=$ baris lama - (koefisien perkolom kunci $*$ nilai baris kunci).
a. $2,5-(2,5-1)=0$
b. $0-(2,5-0)=0$
c. $\quad 0-(2,5-0)=0$
d. $\quad 1-(2,5-0)=1$
e. $0-(2,5-0)=0$
f. $\quad 0-(2,5-0,2)=-0,5$
g. $3-(2,5-1)=0,5$

Maka hasil yang didapat dari perhitungan S3 adalah $0,0,0,1,0,-0,5$ dan 0,5.

\begin{tabular}{ccccccccc}
\multicolumn{2}{l}{ Baris S4 } \\
\hline S4 & 0 & 0 & 0 & 0 & 0,2 & 0 & 1,4 & 0 \\
S5 & 1 & 0 & 0 & 0 & 0 & 0 & 0.2 & 1 \\
\hline
\end{tabular}

Baris baru $=$ baris lama $-($ koefisien perkolom kunci $*$ nilai baris kunci).
a. $\quad 0-(0-1)=0$
b. $0-(0-0)=0$
c. $0-(0-0)=0$
d. $\quad 0-(0-0)=0$
e. $\quad 0,2-(0-0)=0,2$
f. $\quad 0-(0-0,2)=0$
g. $1,4-(0-1)=1,4$

Maka hasil yang didapat dari perhitungan S4 adalah $0,0,0,0,0.2,0$ dan 1.4

Masukkan nila- nilai baris baru ke dalam tabel (lihat Tabel 8). 
Tabel 8. Hasil optimasi

\begin{tabular}{lccccccccc}
\hline Var & Z & X1 & X2 & S1 & S2 & S3 & S4 & S5 & NK \\
\hline Z & 1 & 0 & 0 & 0 & 0 & 0 & 54.200 & 23.10 & $\mathbf{4 9 4 . 9 0 0}$ \\
S1 & 0 & 0 & 0 & 5 & 0 & 0 & $-0,2$ & -1 & 8 \\
S2 & 0 & 0 & 0 & 0 & 1 & 0 & -0.5 & 0 & 0.5 \\
S3 & 0 & 0 & 0 & 0 & 0 & 1 & 0 & $-0,5$ & 0,5 \\
S4 & 0 & 1 & 0 & 0 & 0 & 0 & 0,2 & 0 & 1,4 \\
S5 & 0 & 0 & 1 & 0 & 0 & 0 & 0 & 0,2 & 1 \\
\hline
\end{tabular}

Berdasarkan Tabel 8 baris $\mathrm{Z}$ tidak ada lagi yang bernilai negatif sehingga solusi yang diperoleh sudah optimal, maka keuntungan maksimum yang diperoleh Oma Corry adalah sebesar Rp.494.900,- per produksi setiap hari.

\subsection{Penerapan}

Agar menjadi lebih efisien maka digunakan teknologi informasi berupa tools POM-QM for windows sekaligus sebagai pengujian terhadap hasil yang didapat sebelumnya. Berikut langkah-langkah pemecahan PL (metode simpleks) menggunakan tools POM-QM for windows.

1) Saat menjalankan tools otomatis menu modul akan muncul. Untuk persoalan PL, maka pilih modul Linier Programming (lihat Gambar 2).
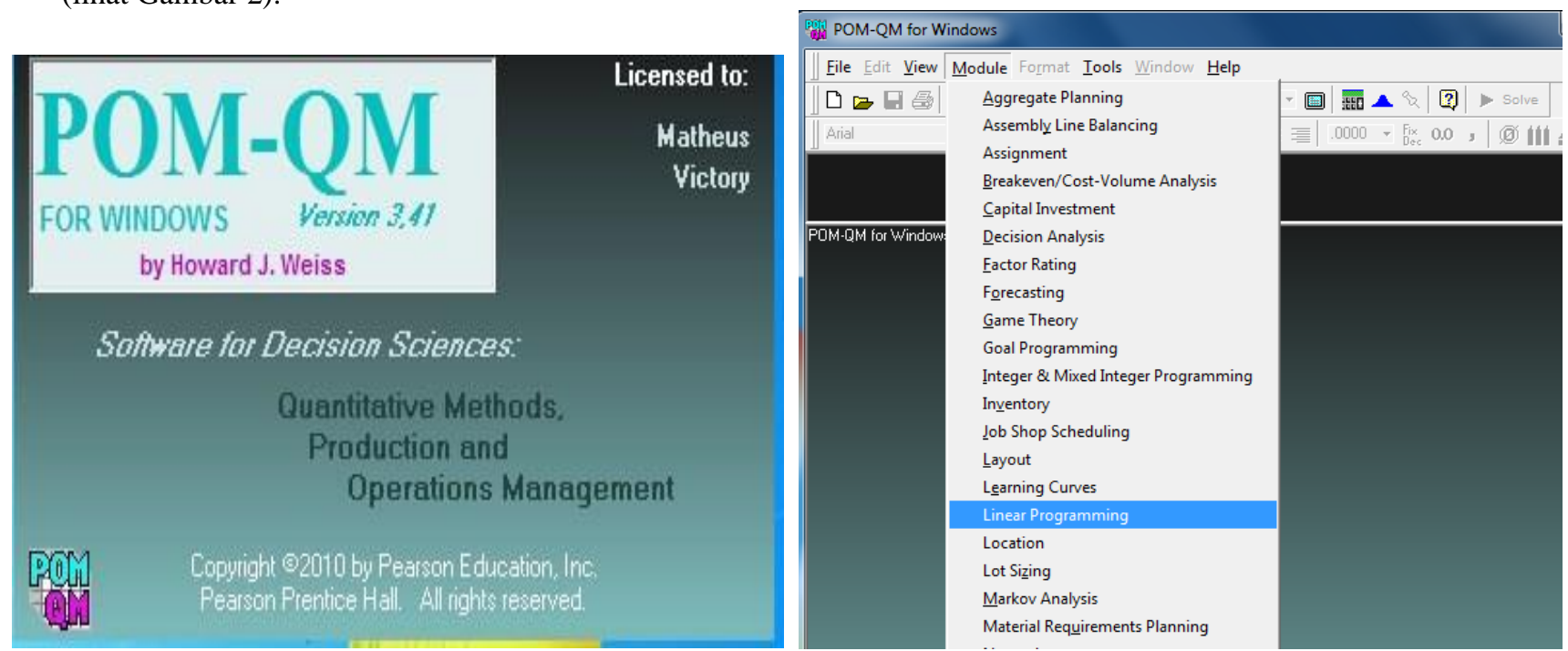

Gambar 2. Tampilan Awal dan Pilihan Modul Pada POM-QM for Windows

2) Untuk membuat file baru, pilih menu File kemudian pilih New (lihat Gambar 3).

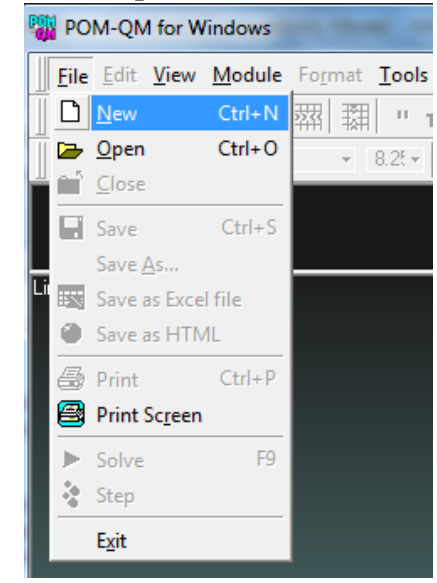

Gambar 3. Tampilan Membuat File Baru Pada POM-QM for Windows

3) Setelah itu akan muncul form pengisian data yang akan diolah, mulai dari judul, jumlah kendala, jumlah variabel, pemilihan maksimum atau minimum, nama kolom serta nama baris (lihat Gambar 4). 


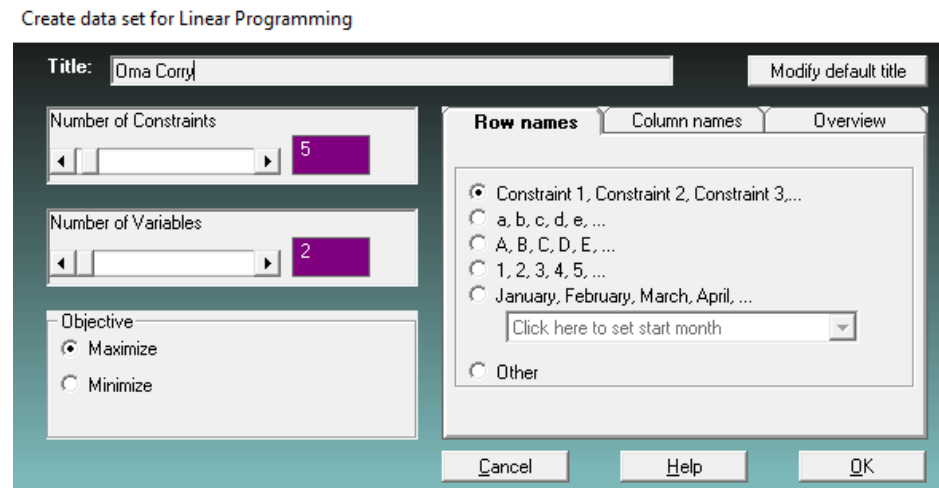

Gambar 4. Tampilan Form Masukkan Data PL

4) Kemudian data produksi dari Oma Corry dimasukan ke dalam kolom yang telah disediakan oleh tools (lihat Gambar 5).

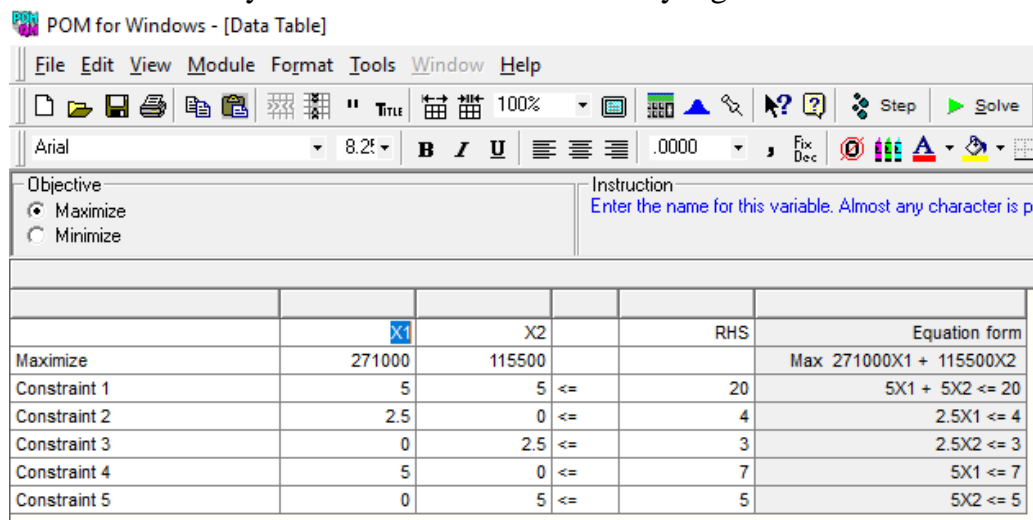

Gambar 5. Tampilan Form Masukkan Data Produksi

5) Lalu klik tombol solve pada tools kemudian pilih menu literations setelah data selesai dimasukan, maka tools ini secara otomatis akan memberikan hasil atau solusi dari pemecahan masalah dari Oma Corry (lihat Gambar 6).

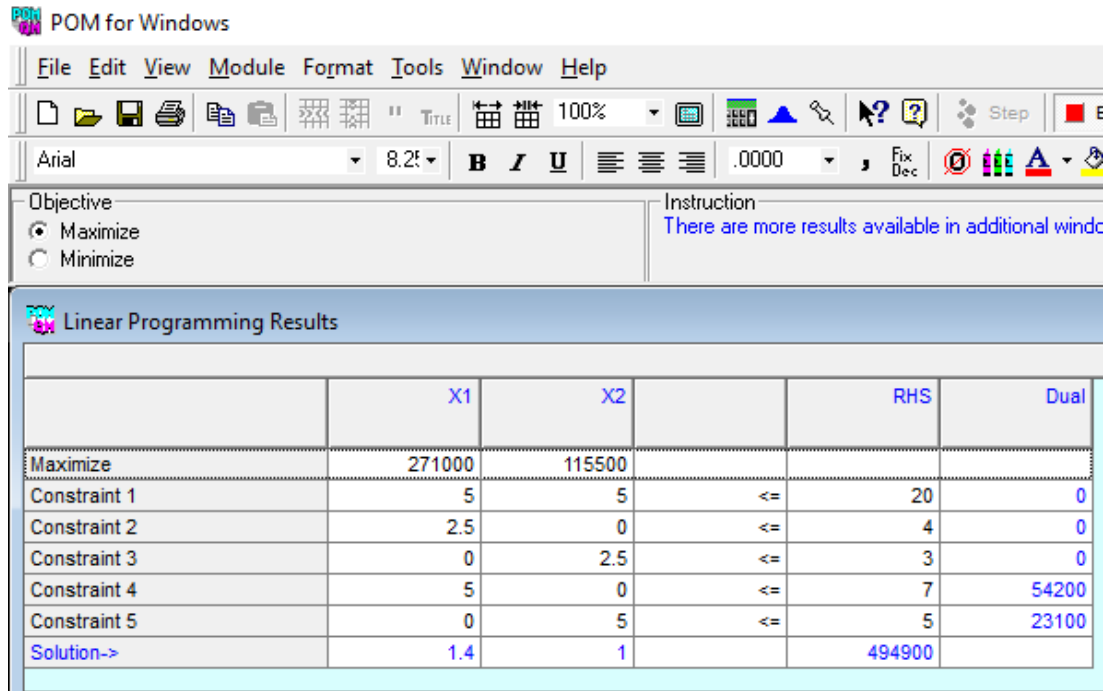

Gambar 6. Tampilan Pemecahan Masalah dan Solusi Akhir

Hasil pengujian menunjukkan bahwa penerapan PL dengan menggunakan tools POM-QM for Windows dapat membantu Oma Corry dalam menghitung keuntungan maksimum dari keterbatasan sumber daya yang dimiliki karena cepat, tepat serta akurat (efisien). Hasil perhitungan baik manual maupun menggunakan tools memperoleh hasil keuntungan yang sama yaitu sebesar Rp.494.900,- per produksi setiap minggunya.

\section{KESIMPULAN}

Berdasarkan pembahasan di atas, maka kesimpulan yang dapat diambil adalah: 
1) Program Linier dalam hal ini Metode Simpleks dapat digunakan oleh Oma Corry, sehingga dengan keterbatasan sumber daya yang ada dapat dimanfaatkan untuk memperoleh keuntungan yang maksimal.

2) Pemanfaatan teknologi informasi yaitu tools POM-QM for windows sangat membantu perhitungan karena cepat, tepat serta akurat (efisien).

3) Hasil yang diperoleh Oma Corry dengan menggunakan metode simpleks dan tools POM-QM for windows yaitu sebesar Rp.949.900,- per produksi setiap minggunya.

4) Metode simpleks dapat dijadikan acauan dalam pengambilan keputusan, karena mempercepat Oma Corry untuk berinovasi dalam menghasilkan produk.

\section{REFERENCES}

[1] M. S. Rumetna and I. Sembiring, "PEMANFAATAN CLOUD COMPUTING BAGI USAHA KECIL MENENGAH (UKM)," in Prosiding Seminar Nasional Geotik, 2017, no. ISSN:2580-8796, pp. 1-9.

[2] M. S. Rumetna, "Pemanfaatan Cloud Computing Pada Dunia Bisnis: Studi Literatur," J. Teknol. Inf. dan Ilmu Komput., vol. 5, no. 3, pp. 305-314, 2018.

[3] T. N. Lina, D. Manongga, and A. Iriani, "PENERAPAN FRAMEWORK KNOWLEDGE MANAGEMENT PADA UKM KULIT PARI YOGYAKARTA," in Seminar Nasional GEOTIK, 2017, pp. 139-145.

[4] M. S. Rumetna, D. Manongga, and A. Iriani, "PENERAPAN KNOWLEDGE CAPTURE UNTUK PROMOSI FAKULTAS MENGGUNAKAN SOFT SYSTEM METHODOLOGY ( SSM ) ( STUDI KASUS : FAKULTAS TEKNIK , UNIVERSITAS VICTORY SORONG )," in Prosiding Seminar Nasional Geotik, 2017, pp. 106-116.

[5] M. S. Rumetna, T. N. Lina, T. Aponno, A. Palisoa, and F. Singgir, "Penerapan Metode Simpleks Dan Software POM- QM Untuk Optimalisasi Hasil Penjualan Pentolan Bakso," Ilm. Manaj. Inform. dan Komput., vol. 02, no. 03, pp. 143-149, 2018.

[6] L. Sarmin et al., "PENERAPAN METODE SIMPLEKS UNTUK MENGHITUNG KEUNTUNGAN MAKSIMUM PADA PENGRAJIN GELANG BESI PUTIH DI PASAR REMU SORONG,” J. KUADAS, vol. 1, no. 2, pp. 1-7, 2018.

[7] M. S. Rumetna, T. N. Lina, L. Simarmata, L. Parabang, A. Joseph, and Y. Batfin, "Pemanfaatan POM-QM Untuk Menghitung Keuntungan Maksimum UKM Aneka Cipta Rasa (ACR) Menggunakan Metode Simpleks," in GEOTIK, 2019, pp. 12-22.

[8] M. Rumetna, Supriyanto et al., "PENERAPAN METODE SIMPLEKS UNTUK MENGHASILKAN KEUNTUNGAN MAKSIMUM PADA PENJUAL BUAH PINANG,”J. Dedication To Papua Community2, vol. 2, no. 1, pp. 75-86, 2019.

[9] M. S. Rumetna et al., "Mengoptimalilasi keterbatasan sumber daya untuk memaksimalkan keuntungan penjualan es kelapa muda menggunakan metode simpleks dan software pom-qm," Pengabdi. Masy., vol. 02, no. 02, pp. 136-149, 2019.

[10] R. Ong et al., "Maksimalisasi Keuntungan Pada Usaha Dagang Martabak Sucipto Menggunakan Metode Simpleks Dan POM-QM," Ris. Komput., vol. 6, no. 4, pp. 434-441, 2019.

[11] V. Ngamelubun et al., "Optimalisasi Keuntungan Menggunakan Metode Simpleks Pada Produksi Batu Tela,” Ris. Komput., vol. 6, no. 5, pp. 484-491, 2019.

[12] M. S. Rumetna et al., "MENGHITUNG KEUNTUNGAN MAKSIMAL DARI PENJUALAN ROTI ABON GULUNG DENGAN MENGGUNAKAN METODE SIMPLEKS DAN SOFTWARE POM-QM,”J. Jendela Ilmu, vol. 1, no. 1, pp. 6-12, 2020.

[13] M. S. Rumetna et al., "Optimasi Pendapatan Pembuatan Spanduk dan Baliho Menggunakan Metode Simpleks ( Studi Kasus : Usaha Percetakan Shiau Printing ),” J. Ris. Komput., vol. 7, no. 2, pp. 278-284, 2020. 